\title{
The role of gonadectomy and testosterone replacement on thymic luteinizing hormone-releasing hormone production
}

\author{
N Azad ${ }^{1,2,3}$, N LaPaglia ${ }^{1,3}$, L Agrawal ${ }^{1,2,3}$, J Steiner ${ }^{1,3}$, S Uddin ${ }^{1}$, \\ D W Williams ${ }^{1}$, A M Lawrence ${ }^{1,2,3}$ and N V Emanuele ${ }^{1,2,3,4}$ \\ ${ }^{1}$ Research Service and ${ }^{2}$ Medical Service, Department of Veterans' Affairs, Edward Hines Jr Hospital, Hines, Illinois 60141 , ${ }^{3}$ Department of Medicine and \\ ${ }^{4}$ the Molecular Biology Program, Loyola University of Chicago Stritch School of Medicine, Maywood, Illinois 60153, USA \\ (Requests for offprints should be addressed to N Azad, Endocrinology/Diabetes Section, Veterans' Affairs Hospital, Hines, Illinois 60141, USA)
}

\begin{abstract}
We and others have identified luteinizing hormonereleasing hormone (LHRH) in cells of the immune system in both animals and humans. LHRH is an immunostimulant, and testosterone is an immunosuppressant. Because testosterone is known to modulate the concentrations of hypothalamic LHRH, we wondered whether testosterone might also alter the concentrations of rat thymic LHRH. Two weeks after castration or sham castration, adult male rats were implanted with either vehicle or testosterone capsules. All animals were killed 4 days after capsule implantation. Thymic LHRH concentration increased significantly in castrated animals. Testosterone replacement prevented this increase. The concentration of the LHRH precursor, proLHRH, decreased significantly, but testosterone replacement
\end{abstract}

prevented this decrease. Steady-state concentrations of LHRH mRNA were not changed by castration or by hormonal replacement. In contrast to the post-castration increase in thymic LHRH, LHRH content of the hypothalamus decreased significantly. Whereas concentrations of LHRH were lower in the thymus than in the hypothalamus, proLHRH concentrations were much greater in the thymus. These data suggest that gonadal manipulation modulates LHRH molecular processing and its tissue concentration in the thymus in addition to those in the hypothalamus, and that the regulation of LHRH molecular processing by testosterone in the hypothalamus is different from that in the thymus.

Journal of Endocrinology (1998) 158, 229-235

\section{Introduction}

Recent reports have demonstrated that luteinizing hormone-releasing hormone (LHRH), in addition to having a pivotal role in regulating the hypothalamicpituitary-gonadal axis, is an immunmodulator. Our laboratory and others have shown that LHRH is produced and processed in human and rat lymphocytes (Emanuele et al. 1990, Azad et al. 1991a,b, 1993). Moreover, many studies have demonstrated that LHRH has a significant stimulatory effect on $\mathrm{T}$ cell proliferative activity and other aspects of immune function (Marchetti et al. 1989a,b, Azad et al. 1990a, Batticane et al. 1991, Jacobson et al. 1994). Furthermore, the immunosuppressive effect of gonadal hormones, mainly testosterone, has been known for several decades (Wyle \& Kent 1977, Grossman et al. 1983, Grossman 1984, Blagosklonny \& Neckers 1994). The thymus gland, which is the major source of $\mathrm{T}$ lymphocyte production and has been shown to produce LHRH (Azad et al. 1991a), decreases in size and function after sexual maturation (Weksler et al. 1978, Makinodan \& Kirokawa 1985). However, castration before puberty delays postpubertal thymic involution and preserves $\mathrm{T}$ cell prolifer- ative activity (Castro 1974, Weksler et al. 1978). The presence of testosterone (Kovacs \& Olsen 1987) and dihydrotestosterone (Grossman et al. 1979, McCruden \& Stimson 1981, Meikle et al. 1991) receptors, and the demonstration that gonadal hormones can be metabolized in thymic lymphocytes, further support an immunomodulator role of gonadal steroids (Weinstein et al. 1977, Sholiton et al. 1980).

Because gonadal steroids modify the concentrations of hypothalamic LHRH (Roselli et al. 1990), the following experiments were designed to study the effect of castration and testosterone replacement on the production and molecular processing of thymic LHRH, and to compare those results with the effect of the same manipulations on hypothalamic LHRH.

\section{Materials and Methods}

\section{Animals}

Castrated and sham-castrated male Sprague-Dawley rats, 60-70 days old, were obtained from Harlan SpragueDawley (Indianapolis, IN, USA). The rats were housed in 
groups of two or three at a temperature of $22 \pm 2{ }^{\circ} \mathrm{C}$ and with a $12 \mathrm{~h}$ light $/ 12 \mathrm{~h}$ darkness cycle. Food and water were available ad libitum.

\section{Procedure}

Gonadectomy was performed using standard methods. Male rats, 60 days old, were anesthetized with pentobarbital $(1 \mathrm{mg} / \mathrm{kg})$ i.p. The scrotal sac was cleaned with alcohol and a small incision of approximately $2 \mathrm{~cm}$ was made midsagittally at the scrotal septum. The spermatic cords were dissected, tied and cut. The testes were carefully removed from the scrotal sac. The incision was sutured. In sham operations, the scrotal incisions were immediately sutured and the gonadal system was not manipulated. The entire procedure was performed under aseptic conditions. Animals were allowed to recover from the anesthesia and, when they were able to eat and drink, they were returned to the animal quarters.

Two weeks after castration, castrated rats were implanted s.c. with a silastic capsule containing either vehicle or testosterone and the sham-castrated rats were implanted with vehicle capsules only. Testosterone (CIBA, Summit, NJ, USA) capsules were made using Silastic tubing (inside diameter $0.062 \mathrm{~mm}$; outside diameter $0.125 \mathrm{~mm}$ ) purchased from Dow-Corning (Midland, MI, USA). The animals were killed $96 \mathrm{~h}$ after the implantation of the silastic capsules (Azad et al. 1990b).

The data presented were pooled from several experiments, and do not contain equal numbers of animals in each case presented. Data were not arbitrarily discarded. Some thymuses were analyzed for LHRH mRNA by reverse transcription (RT)-PCR; some were used for LHRH assay and some were used to assay the precursor of LHRH, proLHRH. Because of shortages of proLHRH antibody at the time of the experiment, we were not able to analyze all of the thymuses for proLHRH.

\section{Processing of tissues}

The rats were killed by decapitation, and the hypothalamus and thymus were quickly dissected out. Trunk blood was collected, and serum stored at $-20^{\circ} \mathrm{C}$. The tissues used to assay proLHRH RNA were immediately placed in liquid nitrogen, then stored at $-70{ }^{\circ} \mathrm{C}$.

To process the tissues for RIA, the thymuses were immediately weighed and homogenized in chilled $0.01 \mathrm{M}$ PBS, pH $7 \cdot 4$, at a concentration of $25 \mathrm{mg} / \mathrm{ml}$, using a Tekmar tissuemizer. They then were centrifuged at 2000 r.p.m. $(1720 \mathrm{~g})$ for $30 \mathrm{~min}$ in a Sorvall RC-5B refrigerated centrifuge, and the supernatant kept at $-20^{\circ} \mathrm{C}$ until required for RIA. On the day of the RIA, the supernatant was thawed and filtered using a 25-mm syringe filter unit (PGC Scientific, Gaithersburg, MD, USA). After removal from the animals, the hypothalami were immediately frozen in liquid nitrogen and kept at $-70{ }^{\circ} \mathrm{C}$. On the day of the RIA, the hypothalami were thawed and homogenized with a Tekmar tissuemizer in chilled 0.01 M PBS, $\mathrm{pH} 7 \cdot 4$, at a concentration of 1 hypothalamus/ml, centrifuged in the same way as thymuses, and supernatant taken for RIA the same day. All the tissue processing was performed on ice.

On the basis of experience gained in our laboratory, this method of tissue processing for LHRH and proLHRH RIA was demonstrated to be much simpler, yet yielded the same amount of peptides in RIA compared with other methods of tissue preparation for LHRH and proLHRH.

\section{LHRH and proLHRH RIA}

The LHRH RIA was conducted, as described previously (Azad et al. 1993), using antiserum (CRR11B73) graciously supplied by Dr Victor Ramirez of the University of Illinois (Champaign-Urbana, IL, USA). The assay sensitivity was $15.6 \mathrm{pg} / \mathrm{ml}(3 \cdot 1 \mathrm{pg} /$ tube $)$, and the intra- and interassay coefficients of variation were $5 \cdot 1 \%$ and $15 \%$ respectively.

ProLHRH RIA was performed using antiserum and proLHRH for standard and iodination kindly supplied by Dr John P Adelman, Oregon Health Sciences University (Portland, OR, USA) as previously described (Azad et al. 1993). ARK2 antiserum specifically recognizes the proLHRH molecule and was directed against amino acid residues 6-16, which span the cleavage site between LHRH and LHRH-related peptide in the proLHRH molecule. This antiserum has virtually no cross reactivity with the mature LHRH peptide (Roselli et al. 1990). The sensitivity of the assay was $78 \mathrm{pg} / \mathrm{ml}$, and the intra- and interassay coefficients of variation were $4 \%$ and $12 \%$ respectively.

\section{Testosterone RIA}

Testosterone RIA was performed using a kit purchased from Pantex (Pantex, Santa Monica, CA, USA). The sensitivity of the assay was $2 \mathrm{pg}$, equivalent to $0 \cdot 1 \mathrm{ng} / \mathrm{ml}$ in serum, and the intra- and interassay coefficients of variation were $8 \%$ and $12 \%$ respectively.

\section{Reverse transcription-polymerase chain reaction}

The following primer pairs were used in these experiments: LHRH (exon 2) 5'-GCCAATTCAAAAACTC CTAGCTGGCC-3', LHRH (exon 4) 5'-ATCTTCTT CTGCCCAGTTTCCTCTT-3'. The expected product of $375 \mathrm{bp}$ was produced after PCR amplification. The histone $\mathrm{H} 3 \cdot 3$ primers produced a PCR product of $213 \mathrm{bp}$.

\section{$R N A$ isolation, reverse transcription-polymerase chain reaction}

The methodology for semiquantitative or comparative RT-PCR has been previously described (Chomczynski \& 
Sacchi 1987, Azad et al. 1993, Kelley et al. 1993). Briefly, total RNA was extracted from the cells according to the procedure of Chomczynski \& Sacchi (1987) as previously described. This procedure results in RNA isolation without genomic DNA contamination. Three micrograms of total RNA were added to a reaction tube containing $50 \mathrm{mM}$ Tris- $\mathrm{HCl}$ (pH 8.3), $75 \mathrm{mM} \mathrm{KCl}, 3 \mathrm{mM} \mathrm{MgCl}_{2}$, $10 \mathrm{mM}$ dithiothreitol, $2 \mathrm{mM}$ of each deoxynucleotide triphosphate (dNTP), $10 \mathrm{U}$ RNasin (RNase inhibitor, Promega, Madison, WI, USA), 100 pmol oligo-(dT) primers (Bethesda Research Laboratories, Gaithersburg, MD, USA), and RNase-free deionized distilled water to a final volume of $19 \mu \mathrm{l}$. This mixture was heated for $10 \mathrm{~min}$ at $65{ }^{\circ} \mathrm{C}$ and quenched on ice, then $200 \mathrm{U}$ Moloney murine leukemia virus $\mathrm{RNase}-\mathrm{H}$ reverse transcriptase (Superscript, Bethesda Research Laboratories) in $1 \mu \mathrm{l}$ were added to give a total reaction volume of $20 \mu \mathrm{l}$. This mixture was incubated at room temperature for $10 \mathrm{~min}$, and then at $42{ }^{\circ} \mathrm{C}$ for $1 \mathrm{~h}$. The reaction was terminated by heating at $95^{\circ} \mathrm{C}$ for $5 \mathrm{~min}$ and quenching on ice. RNase-H (2 $\mathrm{U})$ was then added to the reaction and incubated for $20 \mathrm{~min}$ at $37^{\circ} \mathrm{C}$. Five microliters of the reverse transcription reaction from each sample were diluted into a final volume of $100 \mu \mathrm{l}$ in $10 \mathrm{mM}$ Tris $-\mathrm{HCl}$ (pH 8.3), $50 \mathrm{mM} \mathrm{KCl}, 1.5 \mathrm{mM} \mathrm{MgCl}_{2}, 200 \mu \mathrm{M}$ each of deoxynucleotide triphosphate, $0.01 \%$ gelatin, $0 \cdot 01 \%$ Tween-20, $0 \cdot 01 \%$ Nonidet P-40, $2 \mu \mathrm{M}$ of each oligonucleotide, and $2 \mathrm{U}$ Taq-thermostable polymerase (Epicentre, Madison, WI, USA). The polymerase amplification was carried out using an MJ Research programmable heating/cooling dry block for 23 cycles of amplification $\left(94^{\circ} \mathrm{C}, 30 \mathrm{~s} ; 60^{\circ} \mathrm{C}, 1 \mathrm{~min} ; 72{ }^{\circ} \mathrm{C}, 2 \mathrm{~min}\right)$, followed by $10 \mathrm{~min}$ at $72^{\circ} \mathrm{C}$. Negative controls were run in parallel, and consisted of a reaction performed as described above, but without the addition of reverse transcriptase. PCR products labeled with phosphorus-32 were transferred to nytram paper, then exposed to radiographic film. The density of the PCR product on film was measured by densitometer and expressed as arbitrary densitometry units (ADU).

\section{Statistical analysis}

A one-way ANOVA was applied to analyze the effect of gonadal manipulation on hypothalamic and thymic LHRH and proLHRH. Tukey's test was used for multiple comparisons between the three experimental groups: sham-castrated, castrated, and castrated replaced with testosterone.

\section{Results}

To confirm the effect of gonadal manipulation on serum testosterone, sera of several randomly selected rats were studied. The overall effect of gonadal manipulation was significant by ANOVA $(P<0 \cdot 001)$. The serum concentration of testosterone decreased from $3.78 \pm 0.6 \mathrm{ng} / \mathrm{ml}$ $(n=5)$ in sham-castrated animals, to $1 \cdot 05 \pm 0 \cdot 2 \mathrm{ng} / \mathrm{ml}$ $(n=5)$ in castrated animals $(P<0 \cdot 01)$. The serum testosterone concentration in testosterone-replaced animals was $3 \cdot 72 \pm 0.3 \mathrm{ng} / \mathrm{ml}(n=4)$, essentially identical to that in the sham-operated group and significantly greater than that seen in the castrated group $(P<0 \cdot 01)$.

The effects of gonadectomy and testosterone replacement on thymic LHRH concentration (the amount of LHRH per $\mathrm{mg}$ of tissue) and molecular processing from proLHRH to LHRH were studied. Two weeks after surgery, sham-castrated rats were implanted with vehicle capsules and castrated rats were implanted with testosterone or vehicle capsules; animals were killed $96 \mathrm{~h}$ later.

The overall effect of gonadal manipulation on thymic LHRH concentration was significant $(P<0.0026$ by ANOVA). The thymic LHRH concentration increased from $3 \cdot 1 \pm 0 \cdot 3 \mathrm{pg} / \mathrm{mg}$ tissue $(n=23)$ in sham-castrated animals to $6 \pm 0.95 \mathrm{pg} / \mathrm{mg}$ tissue $(n=18) 2$ weeks after castration $(P=0 \cdot 05)$. Thymic LHRH concentration returned to that observed in the sham-operated rats $(3 \cdot 1 \pm 0 \cdot 4 \mathrm{pg} / \mathrm{mg}$ tissue; $n=10)$ when gonadectomized rats were treated with testosterone (Fig. 1, upper panel). This value was not different from that in sham-castrated rats, but it was significantly lower than the LHRH concentration seen in gonadectomized, non-testosterone-replaced animals $(P=0 \cdot 05)$.

The overall effect of gonadal manipulation on thymic proLHRH concentration was significant by ANOVA $(P<0 \cdot 024)$. Thymic proLHRH concentration decreased from $77 \cdot 4 \pm 10 \cdot 3 \mathrm{pg} / \mathrm{mg}$ tissue $(n=12)$ in sham-castrated rats to $43 \pm 4 \mathrm{pg} / \mathrm{mg}$ tissue $(n=11)$ in castrated animals $(P=0 \cdot 05)$. Testosterone replacement restored thymic proLHRH to $80 \cdot 4 \pm 16.8 \mathrm{pg} / \mathrm{mg}$ tissue $(n=7 ; P=0 \cdot 05$ compared with castrated, vehicle-replaced rats), which did not differ from the concentration in sham-castrated rats (Fig. 1, lower panel). Thymic proLHRH concentration changed in a direction opposite to that observed for LHRH.

The overall effect of gonadal manipulation on thymic weight was highly significant by ANOVA $(P<0 \cdot 0001)$. As expected, thymic weight increased (from $440 \pm 19 \mathrm{mg}$ $(n=15)$ in sham-castrated rats to $793 \pm 26 \mathrm{mg} \quad(n=12)$ in castrated animals, $P<0 \cdot 001$; Fig. 2). Testosterone replacement reduced thymus weight to $662 \pm 22 \mathrm{mg}$ $(n=14)$, which was significantly lower than that in castrated animals $(P<0 \cdot 001)$, but still higher than that in sham-castrated animals (Fig. 2).

The overall effect of gonadal manipulation on total thymic LHRH content (total amount of LHRH in whole thymus) in this experiment was significant by ANOVA $(P<0 \cdot 0025)$. Total thymic LHRH content increased from $1537 \pm 133 \mathrm{pg}(n=14)$ in sham-castrated animals to $3832 \pm 826 \mathrm{pg}(n=12)$ in castrated animals $(P<0 \cdot 01)$. 

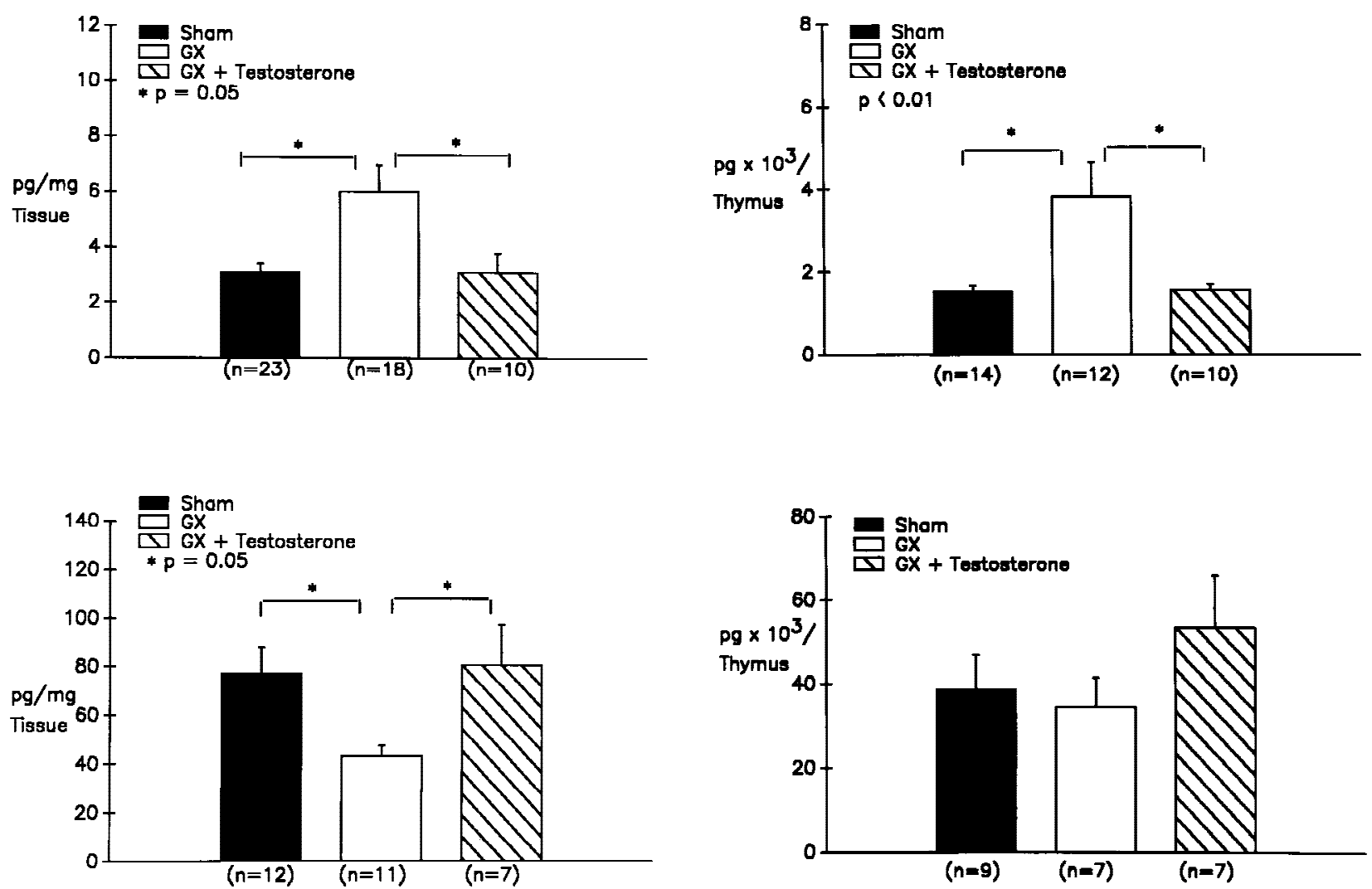

Figure 1 Upper panel: Effect of castration and testosterone replacement on thymic LHRH concentration. Lower panel: Effect of castration and testosterone replacement on thymic proLHRH concentration. Sham, sham-castrated; GX, castrated.

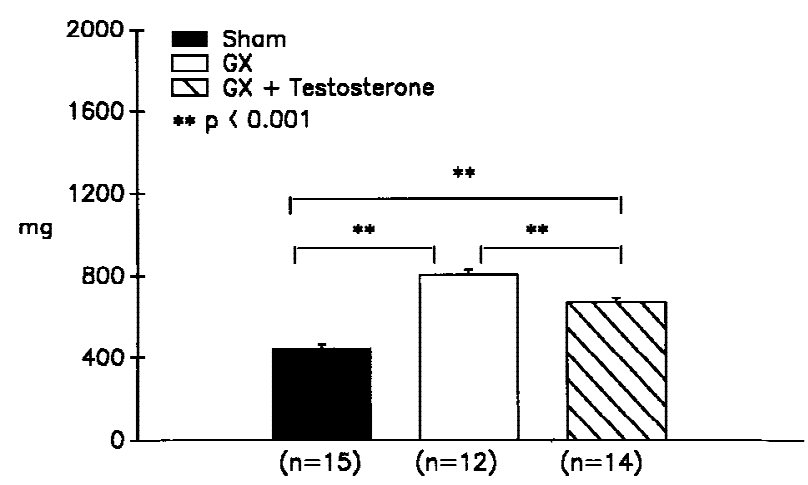

Figure 2 Effect of castration and testosterone replacement on thymus weight. Sham, sham-castrated; GX, castrated.

Ninety-six hours after testosterone replacement, the thymic content of LHRH in castrated animals decreased to $1564 \pm 147 \mathrm{pg}(n=10 ; P<0 \cdot 01$ compared with castrated, non-testosterone-replaced animals; Fig. 3, upper panel). Changes in thymic proLHRH content in the various experimental groups were in the same direction as those in thymic proLHRH concentration, but did not reach statistical significance (Fig. 3, lower panel).

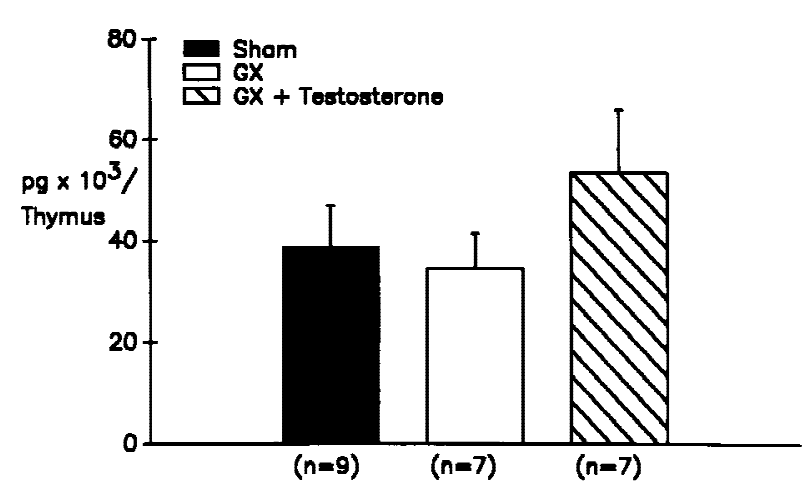

Figure 3 Upper panel: Effect of castration and testosterone replacement on total thymic LHRH content. Lower panel: Effect of castration and testosterone replacement on thymic proLHRH content. Sham, sham-castrated; GX, castrated.

We also examined the effect of castration and testosterone replacement on LHRH mRNA expression in the thymus (Fig. 4). Because of large differences in LHRH mRNA expression in individual animals, the effect of gonadal manipulation did not reach statistical significance. The density of PCR product increased from $469 \pm 23$ ADU in intact rats $(n=4)$ to $605 \pm 204$ ADU $(n=3)$ in gonadectomized rats. Testosterone treatment restored this value to $483 \pm 54$ ADU $(n=4)$.

The overall effect of gonadal manipulation on hypothalamic LHRH was significant $(P<0 \cdot 0024$ by ANOVA). Total hypothalamic LHRH content decreased from $2809 \pm 37 \mathrm{pg} /$ hypothalamus $(n=10)$ in sham-operated rats, to $1949 \pm 197 \mathrm{pg} /$ hypothalamus $(n=7)$ in castrated animals $(P=0 \cdot 05)$. Testosterone replacement increased hypothalamic LHRH to $2487 \pm 140 \mathrm{pg}$ /hypothalamus $(n=5 ; P=0.05$ compared with castrated, non-testosteronereplaced rats), which did not differ from the value in sham-castrated rats (Fig. 5 upper panel). The hypothalamic content of proLHRH was not significantly changed by experimental manipulation: it was $580 \pm$ $69 \mathrm{pg}$ /hypothalamus $(n=14)$ in sham-operated animals, 


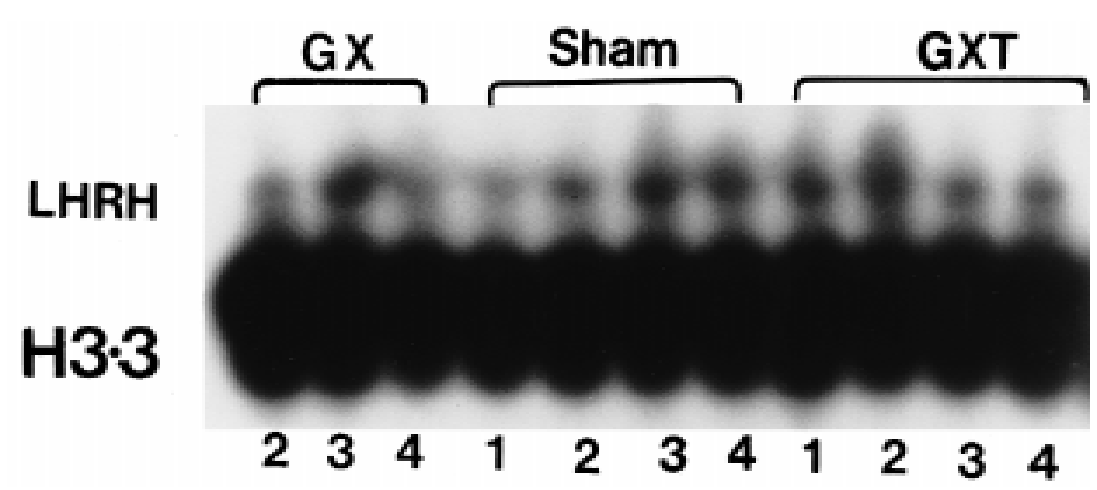

Figure 4 RT-PCR analysis of the effect of gonadectomy and testosterone replacement on steady state concentrations of LHRH mRNA. Each lane represents the thymus from one animal. GX, castrated; Sham, sham-castrated; GXT, castrated and replaced with testosterone. Histone $3 \cdot 3(\mathrm{H} 3 \cdot 3)$ was used as a control for loading and amplification.

$558 \pm 96 \mathrm{pg} /$ hypothalamus $(n=7)$ in rats 2 weeks after castration, and $406 \pm 16 \mathrm{pg}$ /hypothalamus $(n=8)$ in castrated animals treated with testosterone (Fig. 5, lower panel).
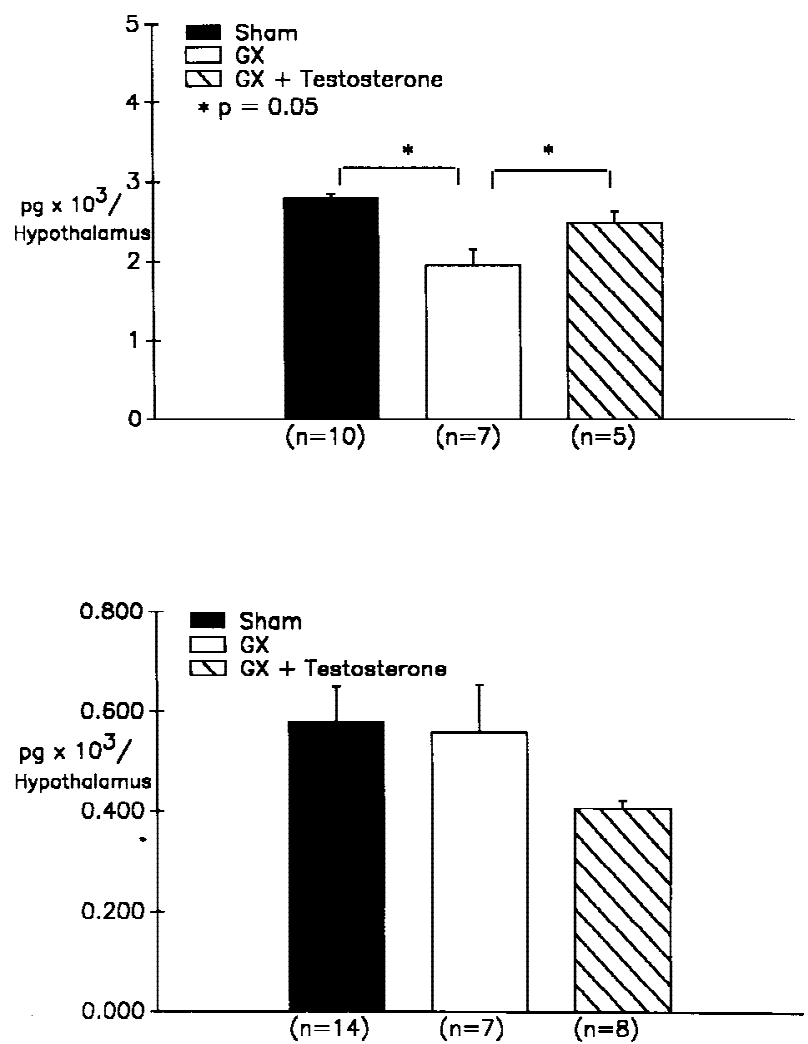

Figure 5 Upper panel: Effect of castration and testosterone replacement on hypothalamic LHRH content. Lower panel: Effect of castration and testosterone replacement on hypothalamic proLHRH content. Sham, Sham-castrated; GX, castrated.

\section{Discussion}

Several lines of evidence support an immunostimulatory role for LHRH. Immunoreactive and bioactive LHRH has been demonstrated to be present in rat and human $\mathrm{T}$ lymphocytes (Emanuele et al. 1990, Azad et al. 1991a,b, 1993). In addition, demonstration of the presence of proLHRH mRNA in these tissues confirms local synthesis (Azad et al. 1991, 1993). The presence of LHRH receptor sites on lymphocytes has been reported in several species (Marchetti et al. 1989a, Standaert et al. 1992). Immunologic stimulation with phytohemagglutinin or antireceptor antibody significantly increased $\mathrm{T}$ cell LHRH production in human and rat T cells (Azad et al. 1990a, 1993 and unpublished observations). This upregulation is PKC- and tyrosine kinase-dependent (Mohagheghpour et al. 1995). It has been shown that LHRH agonist increased $\mathrm{T}$ cell proliferative activity of rat splenic and thymic lymphocytes (Emanuele et al. 1990, Azad et al. 1991 a,b, 1993). Chronic treatment with an LHRH agonist regenerated the involuted thymus gland in aged rats and improved the compromised $\mathrm{T}$ cell proliferative activity in aged female and male rats (Marchetti et al. 1989b). Furthemore, LHRH agonist treatment increased interleukin-2 receptor expression in resting and conconavalin-A-treated thymic and splenic lymphocytes (Batticane et al. 1991).

It has also been demonstrated that LHRH has an important role in an immunostimulated state. LHRH antagonist administration to lupus-prone mice decreased antibody production and hematuria, and significantly increased the animals' life spans (Jacobson et al. 1994), suggesting that this autoimmune state is, in part, dependent upon excessive expression of immune cell LHRH.

Testosterone, a testicular androgen, had been shown to be an immunosuppressor (Grossman 1984). Castration of 
prepubertal male rats delayed involution of the thymus gland (Castro 1974, Weksler et al. 1978). In addition, castration during senescence reversed the age-related loss of cell-mediated immunity (Chiodi 1976), but administration of testosterone prevented this process (Ablin et al. 1974, Chiodi 1976, Grossman 1984, Kelley et al. 1988). Dihydrotestosterone (DHT), the active metabolite of testosterone, and testosterone itself had inhibitory effects on the production of various antibodies and retarded the progression of autoimmune disdorders in $\mathrm{N} 2 \mathrm{~B} / \mathrm{NZW}$ mice (Steinberg et al. 1979). A recent study demonstrated that testosterone and DHT reverse the castration-induced expansion of pre-B cells in bone marrow, and that this effect was independent of the thymus gland (Kovacs et al. 1996).

We have shown for the first time that testosterone modulated thymic proLHRH and LHRH concentrations. The concentration of LHRH in the thymus gland increased after castration, whereas proLHRH decreased. These effects were totally prevented by replacement with testosterone (Fig. 1). Similarly, LHRH content increased after castration, an effect again totally prevented by testosterone replacement (Fig. 3). The decreased proLHRH and increased LHRH, coupled with unchanged LHRH mRNA in castrated rats, indicate that testosterone acted post-translationally to inhibit processing of LHRH from its precursor molecule, proLHRH.

Our studies, in agreement with the findings of many previous investigations (Grossman 1984, Marchetti et al. 1989b), showed significant enlargement in the size of the thymus gland after castration and partial inhibition of this increase in thymic size with testosterone replacement (Fig. 2). Considering the known immunostimulatory effect of LHRH on T cells, our data are consistent with the hypothesis that the increased concentrations of LHRH in the thymus gland of castrated rats might have played a significant part in thymus growth and $\mathrm{T}$ cell development of these animals.

The inhibitory effect of testosterone on thymic LHRH concentrations, coupled with the well-known immunosuppressive effect of testosterone, suggest that the mechanism of the inhibitory role of testosterone on the immune system may be, in part, achieved by its diminishing the concentrations of LHRH in lymphocytes.

The second objective of this study was to compare the effect of castration and testosterone replacement on hypothalamic LHRH with their effect on thymic LHRH. In accordance with the observations of others (Roselli et al. 1990), our data showed that castration significantly decreased hypothalamic LHRH content, by $31 \%$, and that testosterone replacement restored hypothalamic LHRH to sham control values (Fig. 5). This is in direct contrast to the effect on the thymus, indicating markedly different, organ-specific regulatory patterns.

Finally, this is the first report examining the relative contents of LHRH in the hypothalamus and immune tissue. Our data showed comparable concentrations of LHRH in the two tissues, but a much greater content of proLHRH in the thymus. It is thus tempting to speculate that neuroendocrine and immune tissues may possess marked differences in their rates of processing of proLHRH to LHRH. Future investigations are required to examine this issue.

In summary, castration increased the thymic concentration of LHRH, and decreased thymic proLHRH, whereas testosterone treatment prevented these effects. In contrast, the hypothalamic concentration of LHRH was significantly decreased in castrated rats, but normalized with testosterone treatment. In addition, the thymus contains much more proLHRH, but less LHRH, than the hypothalamus. These data suggest that gonadal manipulation modulates thymic LHRH molecular processing and its tissue concentration, in addition to that in the hypothalamus, and that the regulation of LHRH molecular processing by testosterone is different in the hypothalamus and in the thymus.

\section{Acknowledgements}

This work was supported by the Department of Veterans Affairs Medical Research Service.

\section{References}

Ablin RJ, Bruns GR, Guinan P \& Bush IM 1974 Antiandrogenic suppression of lymphocytic blastogenesis: in vitro and in vivo observations. Experientia 30 1351-1353.

Azad N, Emanuele NV, Duffner L, Kirsteins L \& Lawrence AM $1990 a$ Further studies on lymphocyte luteinizing hormone releasing hormone (LHRH). Program of the 72nd Annual Meeting of the Endocrine Society, p 361 (Abstract).

Azad N, Duffner L, Paloyan EB, Reda D, Kirsteins L, Emanuele NV \& Lawrence AM $1990 b$ Hypothalamic prolactin stimulates the release of luteinizing hormone-releasing hormone from male rat hypothalamus. Endocrinology 127 1928-1933.

Azad N, Jurgens J, Young MR, Reda D, Duffner L, Kirsteins L, Emanuele NV \& Lawrence AM 1991a Presence of luteinizing hormone-releasing hormone in rat thymus. Progress in NeuroEndocrinImmunology 4 113-120.

Azad N, Emanuele NV, Halloran MM, Tentler J \& Kelley MR $1991 b$ Presence of luteinizing hormone-releasing hormone (LHRH) mRNA in rat spleen lymphocytes. Endocrinology 128 1679-1681.

Azad N, LaPaglia N, Abel K, Jurgens J, Kirsteins L, Emanuele NV, Kelley MR, Lawrence AM \& Mohagheghpour N 1993 Immunoactivation enhances the concentration of luteinizing hormone-releasing hormone peptide and its gene expression in human peripheral T-lymphocytes. Endocrinology 133 215-223.

Batticane N, Morale MC, Gallo F, Farinella Z \& Marchetti B 1991 Luteininzing hormone-releasing hormone signaling at the lymphocyte involves stimulation of interleukin-2 receptor expression. Endocrinology 129 277-286.

Blagosklonny MV \& Neckers LM 1994 Cytostatic and cytotoxic activity of sex steroids against human leukemia cell lines. Cancer Letters 76 81-86.

Castro JE 1974 Orchidectomy and the immune response I. Effect of orchidectomy on lymphoid tissue of mice. Proceedings of the Royal Society of London. Series B: Biological Sciences 1985 425-436. 
Chiodi H 1976 Thymus hypertrophy induced by castration in old male rats and mice. Federation Proceedings 35 277A.

Chomczynski P \& Sacchi N 1987 Single-step method of RNA isolation by guanidinium thiocyanate-phenol-chloroform extraction. Annals of Biochemistry 162 156-159.

Emanuele NV, Emanuele MA, Tentler J, Kirsteins L, Azad N \& Lawrence AM 1990 Rat spleen lymphocytes contain an immunoactive and bioactive luteinizing hormone-releasing hormone. Endocrinology 126 2482-2486.

Grossman CJ 1984 Regulation of the immune system by sex steroids. Endocrinology Reviews 5 435-455.

Grossman CJ, Nathan P, Taylor BB \& Sholiton LJ 1979 Rat thymic dihydrotestosterone receptor: preparation, location and physiochemical properties. Steroids 34 539-553.

Grossman CJ, Sholiton LJ \& Roselle GA 1983 Dihydrotestosterone regulation of thymocyte function in the rat - mediation by serum factors. Journal of Steroid Biochemistry 19 1459-1467.

Jacobson JD, Nisula BC \& Steinberg AD 1994 Modulation of the expression of murine lupus by gonadotropin-releasing hormone analogs. Endocrinology 134 2516-2523.

Kelley KW, Davila DR, Brief S, Sumon J \& Arkins S 1988 A pituitary thymus connection during aging. Annals of the New York Academy of Sciences $\mathbf{5 2 1} 88-98$.

Kelley MR, Jurgens JK, Tentler J, Emanuele NV, Blutt SA \& Emanuele MA 1993 Coupled reverse transcription-polymerase chain reaction (RT-PCR) technique is quantitative and rapid: uses in alcohol research involving low abundance mRNA species. Alcohol 10 185-189.

Kovacs WJ \& Olsen NJ 1987 Androgen receptors in human thymocytes. American Association of Immunology 139 490-493.

Kovacs WJ, Viselli SM, Reese K, Fan J \& Olsen NJ 1996 Androgens influence B cell development by thymic-independent mechanisms. Program of the 10th International Congress of Endocrinology, p 108 (Abstract), San Francisco, USA

McCruden AB \& Stimson WH 1981 Androgen binding cytosol receptors in the rat thymus: physiocochemical properties, specificity and localisation. Thymus 3 105-117.

Makinodan T \& Kirokawa K 1985 Normal aging of the immune system. In Relations between Normal Aging and Disease, p 117. Ed HA Johnson. New York: Raven Press.

Marchetti B, Guarcello V, Morale MC, Bartonloni G, Farinella Z, Cordaro S \& Scapagnini U 1989a Luteinizing hormone-releasing hormone-binding sites in the rat thymus: characteristics and biological function. Endocrinology 125 1025-1036.
Marchetti B, Guarcello V, Morale MC, Bartoloni G \& Scapagnini U 1989 b Luteinizing hormone-releasing hormone (LHRH) agonist restoration of age-associated decline of thymus weight, thymic LHRH receptors, and thymocyte proliferative capacity. Endocrinology 125 1037-1045.

Meikle AW, Dorchuck RW, Araneo BA, Stringham JD, Evans TG, Spruance SL \& Daynes RA 1991 Dehydroepiandrosterone specific receptor and interleukin-2 stimulation in murine T-cells. Program of the 73rd Annual Meeting of the Endocrine Society, p 191 (Abstract).

Mohagheghpour N, Abel K, LaPaglia N, Emanuele NV \& Azad N 1995 Signal requirements for production of luteinizing hormonereleasing hormone by human T cells. Cellular Immunology 163 280-288.

Roselli CE, Kelly MJ \& Ronnekleiv OK 1990 Testosterone regulates progonadotropin-releasing hormone levels in the preoptic area and basal hypothalamus of the male rat. Endocrinology 126 1080-1086.

Sholiton LJ, Grossman CJ \& Taylor BB 1980 Rat thymic homogenates convert testosterone to androgenic metabolites. Journal of Steroid Biochemistry 13 1365-1367.

Standaert FE, Chew BP, DeAvila D \& Reeves JJ 1992 Presence of luteinizing hormone-releasing hormone binding sites in cultured porcine lymphocytes. Biology of Reproduction 46 997-1000.

Steinberg AD, Melez KA, Raveche ES, Reeves JP, Boegel WA, Smathers PA, Taurog JD, Weinlein L \& Duvic M 1979 Approach to the study of the role of sex hormones in autoimmunity. Arthritis and Rheumatism 22 1170-1176.

Weinstein Y, Lindner HR \& Eckstein B 1977 Thymus metabolises progesterone - possible enzymatic marker for $\mathrm{T}$ lymphocytes. Nature 266 632-633.

Weksler ME, Innes JB \& Goldstein G 1978 Immunological studies of aging IV. The contribution of thymic involution to the immune deficiencies of aging mice and reversal with thymopoietin. Journal of Experimental Medicine 148 996-1006.

Wyle RA \& Kent JR 1977 Immunosuppression by sex steroid hormones the effect upon PHA- and PPD-stimulated lymphocytes. Cellular Immunology 27 407-415.

Received 10 September 1997

Revised manuscript received 8 December 1997 Accepted 23 March 1998 